\title{
Heterocyclic imidazo-anthraquinone as an optical sensor: synthesis, characterization and evaluation of the chemosensory ability
}

\author{
R. Cristina M. Ferreira, Susana P. G. Costa and M. Manuela M. Raposo* \\ Centro de Química, Universidade do Minho, Campus de Gualtar, 4710-057 Braga, \\ mfox@quimica.uminho.pt
}

\begin{abstract}
A novel imidazo-anthraquinone derivative $\mathbf{3}$ was synthesized in moderate yield. The photophysical properties of the new compound were studied by UV-vis and fluorescence spectroscopy in ACN. The evaluation of the new compound as a colorimetric chemosensor was carried out by performing spectrophotometric titrations in $\mathrm{ACN}$ and $\mathrm{ACN} / \mathrm{H}_{2} \mathrm{O}$ in the presence of relevant organic and inorganic anions and transition metal cations. Imidazo-anthraquinone $\mathbf{3}$ exhibited great selectivity for the cyanide anion over other anions in $\mathrm{ACN} / \mathrm{H}_{2} \mathrm{O}$ (95:5) solution showing a distinct color change from yellow to pink.
\end{abstract}

Keywords: imidazo-anthraquinone, thiophene, colorimetric sensor, optical chemosensor, "naked-eye" detection, aqueous media. 


\section{Introduction}

The research on selective chromo-fluorogenic sensors for anions, cations and neutral molecules is an exciting topic with recent developments, especially in the possibility of using colorimetric/fluorimetric probes to sense both anions and cations in aqueous solution. In particular, heterocyclic systems which have the ability to act as the recognition unit as well as the signalling unit are very interesting since variation of their absorption/fluorescence properties can happen during the recognition event. With careful design, for example by inclusion of additional heterocycles, the analyte recognition and overall photophysical properties can be improved, leading to higher sensitivity and selectivity. ${ }^{1}$ Imidazole based chromophores have received increasing attention recently due to their distinctive optical properties and excellent thermal stabilities making them versatile systems for several applications such as optical chemosensors and two-photon absorbing molecules, ${ }^{2}$ among other applications in materials and medicinal chemistry. For the recognition of certain anions, anthraquinone derivatives have been reported as suitable systems for colorimetric sensing since they are an example of electron acceptor groups that can be electronically connected with recognition units. ${ }^{3}$

Based on the above facts, herein we report the synthesis of one imidazo-anthraquinone and the characterization of its photophysical and chemosensory properties. The evaluation of the compound as a colorimetric chemosensor was carried out by performing spectrophotometric titrations in $\mathrm{ACN}$ and $\mathrm{ACN} / \mathrm{H}_{2} \mathrm{O}$ in the presence of relevant organic and inorganic anions and transition metal cations.

\section{Experimental}

\subsection{Synthesis of 2-(5'-hexylthiophen-2'-yl)-1H-anthra[1,2-d]imidazole-6,11-dione 3}

i) Preparation of the imine: 1,2-diaminoanthraquinone $\mathbf{1}(0.05 \mathrm{~g}, 0.21 \mathrm{mmol})$ and 5hexylthiophene-2-carboxaldehydeby $2(0.027 \mathrm{~g}, 0.17 \mathrm{mmol})$ were dissolved separately in ethanol $(4 \mathrm{~mL} / \mathrm{mmol})$. The ethanolic solution of aldehyde and formic acid (0.04 $\mathrm{mL} / \mathrm{mmol}$ of aldehyde) was added to the solution of 1,2-diaminoanthraquinone and the reaction mixture was heated under reflux during $8 \mathrm{~h}$. 
ii) Cyclisation of the imine: After cooling, the ethanol was evaporated and the crude imine was dissolved in a small volume of acetic acid $(1 \mathrm{~mL} / \mathrm{mmol}$ of imine). To this solution, lead tetraacetate was added $(0.100 \mathrm{~g}, 0.18 \mathrm{mmol})$ and the mixture was stirred overnight at room temperature. The mixture was poured into water $(10 \mathrm{~mL})$ and extracted with chloroform $(2 \times 20 \mathrm{~mL})$. The organic layer was dried with magnesium sulphate and evaporated under reduce pressure to give compound $\mathbf{3}$, as a solid which was recrystallised from diethyl ether and chloroform.

Compound 3 was obtained as a light yellow solid (44 mg, $43 \%$ ). M.p. $144.1-145.0{ }^{\circ} \mathrm{C}$. UV-vis (acetonitrile): $\lambda_{\max } \mathrm{nm}(\log \varepsilon) 426$ (3.94). ${ }^{1} \mathrm{H}$ NMR (400 MHz, DMSO- $\left.d_{6}\right): \delta=$ $0.93\left(\mathrm{t}, J=7.2 \mathrm{~Hz}, 3 \mathrm{H}, \mathrm{CH}_{3}\right), 1.31-1.44\left(\mathrm{~m}, 6 \mathrm{H}, \mathrm{c}-\mathrm{CH}_{2}, \mathrm{~d}-\mathrm{CH}_{2}, \mathrm{e}-\mathrm{CH}_{2}\right), 1.71-1.79$ (m, 2H, b-CH $), 2.91\left(\mathrm{t}, J=7.2 \mathrm{~Hz}, 2 \mathrm{H}, \mathrm{a}-\mathrm{CH}_{2}\right), 6.92$ (d, $\left.J=4.4 \mathrm{~Hz}, 1 \mathrm{H}, \mathrm{H}-4^{\prime}\right), 7.76-$ 7.83 (m, 3H, H-3', H-8 and H-9), 8.08 (d, $J=8.4$ Hz, 1H, H-5), 8.20 (d, $J=8.4 \mathrm{~Hz}, 1 \mathrm{H}$, H-4), 8.24 (dd, $J=7.2$ and $2.2 \mathrm{~Hz}, 1 \mathrm{H}, \mathrm{H}-10), 8.31$ (dd, $J=7.6$ and $2.4 \mathrm{~Hz}, 1 \mathrm{H}, \mathrm{H}-7$ ) ppm. ${ }^{13} \mathrm{C}$ NMR (100.6 MHz, DMSO- $\left.d_{6}\right): \delta=14.04\left(\mathrm{CH}_{3}\right), 22.53\left(\mathrm{e}-\mathrm{CH}_{2}\right), 28.68$ (d$\left.\mathrm{CH}_{2}\right), 29.67\left(\mathrm{a}-\mathrm{CH}_{2}\right), 30.41\left(\mathrm{~b}-\mathrm{CH}_{2}\right), 31.49\left(\mathrm{c}-\mathrm{CH}_{2}\right), 117.73$ (C-11a), 122.56 (C-4), 124.55 (C-5), 126.07 (C-4'), 126.48 (C-10), 127.60 (C-7), 127.71 (C-2'), 128.56 (C10a), 129.52 (C-3'), 132.54 (C-5a), 133.05 (C-6a), 133.79 (C-8), 133.91 (C-3a), 134.51 (C-9), 147.84 (C-11b), 151.71 (C-2), 153.00 (C-5'), 182.28 (C-11), 185.00 (C-6) ppm. MS (ESI) $m / z(\%): 415\left([\mathrm{M}]^{+}, 100\right)$. HRMS: (ESI) $m / z$ (\%) for $\mathrm{C}_{25} \mathrm{H}_{23} \mathrm{O}_{2} \mathrm{~N}_{2} \mathrm{~S}$; calcd 415.14748; found 415.14695 .

\subsection{Spectrophotometric titrations of compound 3}

UV-visible absorption spectra $(250-650 \mathrm{~nm})$ were obtained using a Shimadzu UV/2501PC spectrophotometer. Fluorescence spectra were collected using a FluoroMax-4 spectrofluorometer. The relative fluorescence quantum yields were determined by using $10^{-6} \mathrm{M}$ solution of quinine sulphate in sulfuric acid as standard $\left(\Phi_{F}\right.$ $=0.54) .{ }^{4}$ Solvents used in the spectroscopic studies were of spectroscopic grade. Solutions of compound $3\left(\mathrm{ca} .1 .0 \times 10^{-5} \mathrm{M}\right)$ and of the ions under study (ca. $1.0 \times 10^{-2}$ and $1.0 \times 10^{-3} \mathrm{M}$ ) were prepared in UV-grade $\mathrm{ACN}$ or $\mathrm{ACN} / \mathrm{H}_{2} \mathrm{O}(95: 5)$. Titrations of compound 3 in the presence of relevant organic and inorganic anions $\left(\mathrm{AcO}^{-}, \mathrm{F}^{-}, \mathrm{Cl}^{-}, \mathrm{Br}^{-}\right.$, $\left.\mathrm{CN}^{-}, \mathrm{NO}_{3}^{-}, \mathrm{BzO}^{-}, \mathrm{H}_{2} \mathrm{PO}_{4}^{-}, \mathrm{HSO}_{4}^{-}\right)$, and transition metal cations $\left(\mathrm{Cu}^{2+}, \mathrm{Cd}^{2+}, \mathrm{Pd}^{2+}, \mathrm{Ni}^{2+}\right.$, $\mathrm{Hg}^{2+}, \mathrm{Zn}^{2+}, \mathrm{Fe}^{2+}, \mathrm{Fe}^{3+}$ and $\mathrm{Cr}^{3+}$ ) was performed by the sequential addition of the ion 
stock solution to the imidazo-anthraquinone solution, in a $10-\mathrm{mm}$ path length quartz cuvette and absorption emission spectra were measured by excitation at the wavelength of maximum absorption with a 2-nm slit.

\section{Results and discussion}

\subsection{Synthesis and characterization}

The reaction between 1,2-diaminoanthraquinone $\mathbf{1}$ and 5-hexylthiophene-2carboxaldehydeby $\mathbf{2}$, by heating at reflux in ethanol with formic acid as catalyst, resulted in the corresponding imine which was cyclised in situ using lead tetraacetate in acetic acid to imidazo-anthraquinone $\mathbf{3}$, in moderate yield (43\%) after purification (Scheme 1). The new compound was completely characterized by the usual spectroscopic techniques (Scheme 1, Table 1).<smiles>Nc1ccc2c(c1N)C(=O)c1ccccc1C2=O</smiles><smiles>CCCCc1ccc(C=O)s1</smiles><smiles>CCCCCc1ccc(-c2nc3ccc4c(c3[nH]2)C(=O)c2ccccc2C4=O)s1</smiles>

Scheme 1. Synthesis of imidazo-anthraquinone 3.

The absorption and emission spectra of compound $\mathbf{3}$ were measured in ACN solution and showed an intense lowest energy charge-transfer absorption band in the UV-visible region at $426 \mathrm{~nm}$. As for the emission, it exhibited a moderate fluorescence quantum yield $\left(\Phi_{F}=0.24\right)$ with the wavelength of maximum emission at $583 \mathrm{~nm}$ and a $157 \mathrm{~nm}$ Stokes' shift (Table 1).

In the ${ }^{1} \mathrm{H}$ NMR spectrum, the NH signal was visible as a brod singlet at $11.04 \mathrm{ppm}$ confirming the formation of the imidazole ring through a intramolecular cyclization of the intermediate imine. 
Table 1. Yields, UV-visible absorption and fluorescence data for imidazoanthraquinone 3 in ACN solution.

\begin{tabular}{ccccccc}
\hline & & \multicolumn{2}{c}{ Absorption } & \multicolumn{3}{c}{ Fluorescence } \\
\cline { 3 - 7 } & $\eta(\%)$ & $\lambda_{\max }(\mathrm{nm})$ & $\log \varepsilon$ & $\lambda_{\mathrm{em}}(\mathrm{nm})$ & $\Phi_{F}$ & $\begin{array}{c}\text { Stokes' } \\
\text { shift }(\mathrm{nm})\end{array}$ \\
\hline $\mathbf{3}$ & 43 & 426 & 3.94 & 583 & 0.24 & 157 \\
\hline
\end{tabular}

\subsection{Spectrophotometric titrations of imidazo-anthraquinone 3 with anions and metallic ions}

Evaluation of new anthraquinone $3\left(10^{-5} \mathrm{M}\right)$ as colorimetric chemosensor was carried out in $\mathrm{ACN}$ and $\mathrm{ACN} / \mathrm{H}_{2} \mathrm{O}$ (95:5) solutions, in the presence of several ions $\left(\mathrm{AcO}^{-}, \mathrm{F}^{-}\right.$, $\mathrm{Cl}^{-}, \mathrm{Br}, \mathrm{CN}^{-}, \mathrm{NO}_{3}^{-}, \mathrm{BzO}^{-}, \mathrm{H}_{2} \mathrm{PO}_{4}^{-}, \mathrm{HSO}_{4}^{-}, \mathrm{Cu}^{2+}, \mathrm{Cd}^{2+}, \mathrm{Pd}^{2+}, \mathrm{Ni}^{2+}, \mathrm{Hg}^{2+}, \mathrm{Zn}^{2+}, \mathrm{Fe}^{2+}, \mathrm{Fe}^{3+}$ and $\mathrm{Cr}^{3+}$ ) with biological, environmental and analytical relevance.

Preliminary tests were carried out by addition of up to 50 equiv of each ion to the solution of anthraquinone 3 in $\mathrm{ACN}$ and in aqueous mixture $\mathrm{ACN} / \mathrm{H}_{2} \mathrm{O}$ (95:5). It was found that compound $\mathbf{3}$ displayed a marked colour change, from yellow to pink (upon interaction with $\mathrm{CN}^{-}, \mathrm{F}^{-}$) and from yellow to light yellow (upon interaction with $\mathrm{Fe}^{2+}$, $\mathrm{Hg}^{2+}$ and $\mathrm{Ni}^{2+}$ ) in ACN solution and it was possible to obtain selectivity for the cyanide in aqueous mixture.

Considering these preliminary results, spectrophotometric titrations of compound $\mathbf{3}$ in ACN with these selected ions were undertaken. Titrations with $\mathrm{CN}^{-}$and $\mathrm{F}^{-}$revealed a trend in the UV-Vis spectra, the intensity of the longest wavelength absorption band at $427 \mathrm{~nm}$ decreased progressively upon addition of the anion, with the simultaneous growth of a new red-shifted absorption band located at $498 \mathrm{~nm}$ (Figure 1). It can be seen that a very small amount of cyanide and fluoride ions (less than 1 equiv) caused large changes in the absorption spectrum, thus showing the high sensitivity of the new sensor to these anions. 

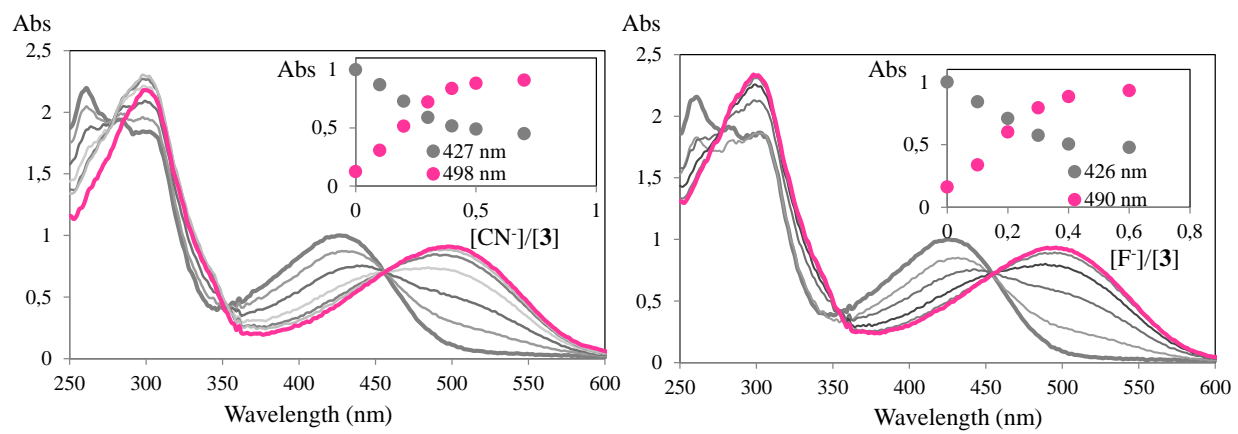

Figure 1. Spectrophotometric titrations of imidazo-anthraquinone 3 with addition of increasing amounts of $\mathrm{CN}^{-}$and $\mathrm{F}^{-}$in $\mathrm{ACN}$. The inset represents the normalized absorption $\left([3]=1 \times 10^{-5} \mathrm{M}, \mathrm{T}=298 \mathrm{~K}\right)$.

In the titration with $\mathrm{Fe}^{2+}, \mathrm{Hg}^{2+}$ and $\mathrm{Ni}^{2+}$, compound 3 revealed a trend in the $\mathrm{UV}-\mathrm{Vis}$ spectra, with the intensity of the longest wavelength absorption band at $427 \mathrm{~nm}$ decreasing progressively upon addition of the cations, with the simultaneous growth of a new blue-shifted absorption band located at $397 \mathrm{~nm}$ (Figure 2). In the titration with $\mathrm{Fe}^{2+} 11$ equiv were used, 4 equiv were needed for titration with $\mathrm{Hg}^{2+}$, and 5 equiv for the titration with $\mathrm{Ni}^{2+}$. Thus, although not selective, compound 3 in $\mathrm{ACN}$ was more sensitive to the presence of anions, considering that only 0.7 equiv of $\mathrm{CN}^{-}$and 0.6 equiv of $\mathrm{F}^{-}$were required for the visible colour change.
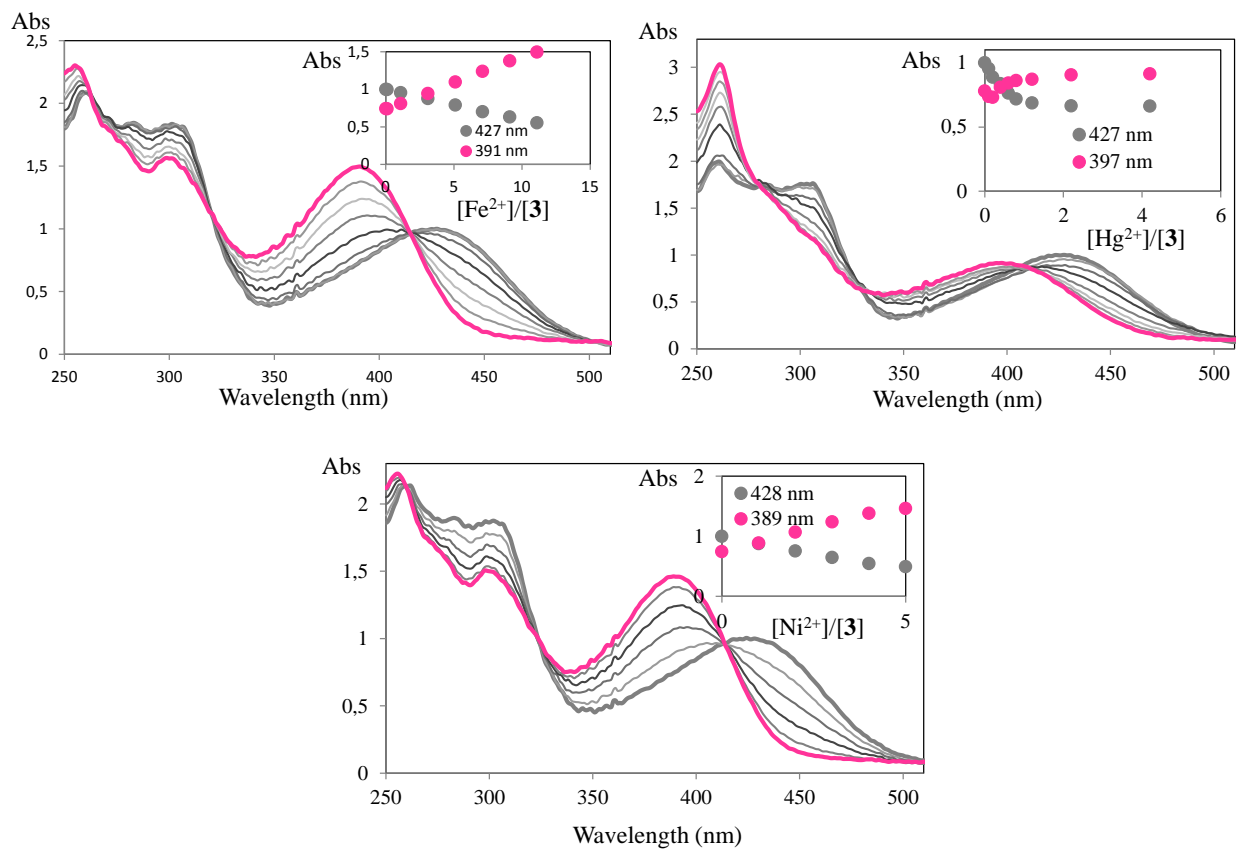

Figure 2. Spectrophotometric titration of $\mathbf{3}$ with addition of increasing amounts of $\mathrm{Fe}^{2+}$, $\mathrm{Hg}^{2+}$ and $\mathrm{Ni}^{2+}$ in $\mathrm{ACN}$. The inset represents the normalized absorption a $427 \mathrm{~nm}([3]=$ $\left.1 \times 10^{-5} \mathrm{M}, \mathrm{T}=298 \mathrm{~K}\right)$. 
In an attempt to increase sensitivity and selectivity, spectrophotometric titrations of compound 3 in $\mathrm{ACN} / \mathrm{H}_{2} \mathrm{O}$ (95:5) were carried out, which confirmed the preliminary sensing results, with compound $\mathbf{3}$ being selective for the cyanide ion although it required a larger amount of ion to achieve a similar colour change (100 equiv), when compared to the titration in ACN. In Figure 3 it can be seen that there was a gradual decrease in absorption intensity upon addition of the cyanide ion, accompanied by a redshift with the formation of a new band at $428 \mathrm{~nm}$.

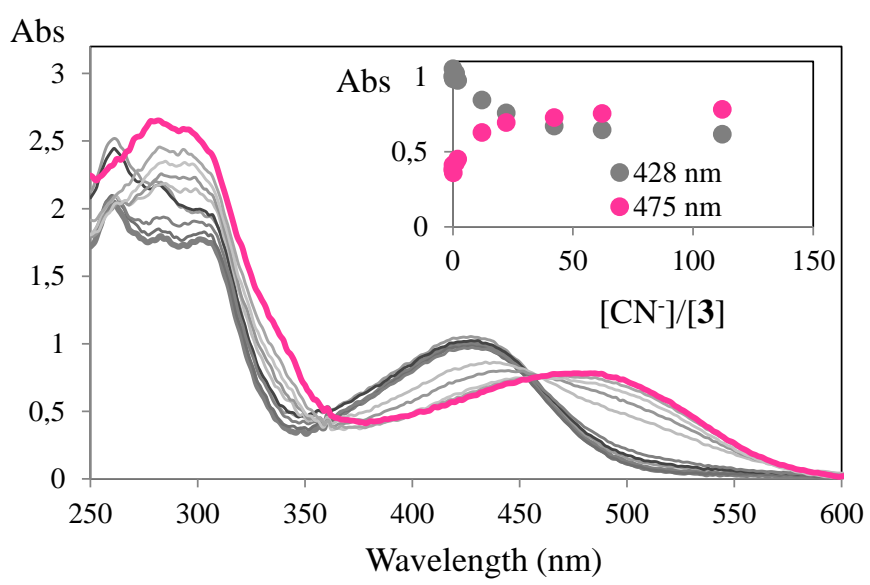

Figure 3. Spectrophotometric titration of compound $\mathbf{3}$ with addition of increasing amounts of $\mathrm{CN}^{-}$in $\mathrm{ACN} / \mathrm{H}_{2} \mathrm{O}$ (95:5). The inset represents the normalized emission ([3] $\left.=1 \times 10^{-5} \mathrm{M}, \mathrm{T}=298 \mathrm{~K}\right)$.

\section{Conclusions}

The synthesis of a new imidazo-anthraquinone $\mathbf{3}$ was achieved in moderate yield by a simple experimental procedure. The sensory ability was evaluated for several ions by spectrophotometric titrations in $\mathrm{ACN}$ and $\mathrm{ACN} / \mathrm{H}_{2} \mathrm{O}$ (95:5). Compound 3 was selective for the cyanide ion in $\mathrm{ACN} / \mathrm{H}_{2} \mathrm{O}$ (95:5), which is a very promising result as a colorimetric chemosensor for application in aqueous media.

\section{Acknowledgements}

Thank are due to Fundação para a Ciência e Tecnologia (Portugal) and FEDERCOMPETE for financial support through Centro de Química (UID/QUI/00686/2013 and UID/ QUI/0686/2016), and a PhD grant to R.C.M. Ferreira (SFRH/BD/86408/2012). The NMR spectrometer Bruker Avance III 400 is part of the National NMR Network and was purchased with funds from FCT and FEDER. 


\section{References}

1. a) M. Formica, V. Fusi, L. Giorgi, M. Micheloni, Coord. Chem. Rev., 2012, 256, 170192.

b) J.-F. Xu, H.-H. Chen, Y.-Z. Chen, Z.-J. Li, L.-Z. Wu, C.-H. Tung, Q.-Z. Yang, Sens. Actuators B, 2012, 168, 14-19.

c) L. E. Santos-Figueroa, M. E. Moragues, E. Climent, A. Agostini, R. MartínezMáñez, F. Sancenón, Chem. Soc. Rev., 2013, 42, 3489-3613.

d) L. You, D. Zha, E. V. Anslyn, Chem. Rev., 2015, 115, 7840-7892.

e) J. Li, S. Chen, P. Zhang, Z. Wang, G. Long, R. Ganguly, Y. Li, Q. Zhang, Chem. Asian J. 2016, 11, 136-140.

2. a) E. Oliveira, R. M. F. Batista, S. P. G. Costa, M. M. M. Raposo, C. Lodeiro, Inorg. Chem., 2010, 49, 10847-10857.

b) C. Marín-Hernández, L. E. Santos-Figueroa, S. Sayed, T. Pardo, M. M. M. Raposo, R. M. F. Batista, S. P. G. Costa, F. Sancenón, R. Martínez-Máñez, Dyes Pigments, 2015, 122, 50-58.

c) Q. Zhang, X. Tian, Z. Hu, C. Brommesson, J. Wu, H. Zhou, J. Yang, Z. Sun, Y. Tian, K. Uvdal, Dyes Pigments, 2016, 126, 286-295.

d) C. I. C. Esteves, M. M. M. Raposo, S. P. G. Costa, Dyes Pigments, 2016, 134, 258-268.

3. a) R. M. F. Batista, E. Oliveira, S. P. G. Costa, C. Lodeiro, M. M. M. Raposo, Org. Lett., 2007, 9, 3201-3204.

b) R. M. F. Batista, S. P. G. Costa, M. M. M. Raposo, J. Photochem. Photobiol. Chem., 2013, 259, 33-40.

c) R. M. F. Batista, E. Oliveira, S. P. G. Costa, C. Lodeiro, M. M. M. Raposo, Supramol. Chem., 2013, 26, 71-80.

d) R. M. F. Batista, S. P. G. Costa, M. M. M. Raposo, Sens. Actuators B: Chem., 2014, 191, 791-799.

e) C. Marín-Hernández, L. E. Santos-Figueroa, M. E. Moragues, M. M. M. Raposo, R. M. F. Batista, S. P. G. Costa, T. Pardo, R. Martínez-Máñez, F Sancenón, J. Org. Chem., 2014, 79, 10752-10761.

4. Ahire, J. H.; Wang, Q.; Coxan, P. R.; Malhotra, G.; Brydson, R.; Chen, R,; Chao, Y. ACS Appl. Mater. Interfaces, 2012, 4, 3285-3292. 